\title{
ANALISIS KEEFEKTIFAN PENGGUNAAN MEDIA WALL CHART (BAGAN DINDING) DENGAN PENDEKATAN FUZZY SERVICE QUALITY DALAM MENINGKATKAN KEMAMPUAN MENULIS KARANGAN ARGUMENTASI SISWA
}

\author{
Retna Ningsih', Wanti Rahayu² \\ Program Studi Teknik Informatika, Universitas Indraprasta PGRI \\ Email: ennatatto@gmail.com ${ }^{1}$,wanti.reiku@gmail.com ${ }^{2}$
}

\begin{abstract}
Abstrak
Beberapa media pembelajaran dapat digunakan untuk pembelajaran menulis, antara lain media wall chart, media gambar seri, media poster, media iklan, dan media brosur. Dalam penelitian ini, peneliti memilih menggunakan media wall chart untuk meningkatkan kemampuan menulis siswa. Media wall chart merupakan salah satu media pandang nonproyeksi. Peranan pokok wall chart dalam pembelajaran adalah untuk melatih penguasaan kosakata dan penyusunan kalimat. Melalui bimbingan dari guru, wall chart dapat berfungsi sebagai jembatan untuk membantu siswa dalam belajar menulis karangan argumentasi. Maka dari itu, peneliti memilih media wall chart sebagai media pembelajaran menulis karangan argumentasi siswa. Penelitian dilakukan dengan menyebarkan kuesioner siswa menggunakan media wall chart dan tanpa menggunakan media wall chart terhadap menulis karangan argumentasi yang saat ini diberikan oleh pihak sekolah. Dari hasil penelitian yang telah dilakukan, didapatkan nilai gap antara menggunakan media wall chart dan tanpa menggunakan media wall chart yang cukup signifikan. Dari hasil perhitungan didapatkan nilai gap kriteria menulis karangan argumentasi (Isi, Struktur Kalimat, Bahasa dan Ejaan dan tanda) yang tepat sebesar -3,2. Nilai gap dimensi kualitas keefektifan tertinggi adalah dimensi reliability sebesar -3,1. Sedangkan nilai gap antara menggunakan media wall dan tanpa menggunakan media wall adalah sebesar -3,361. Hal ini menunjukkan bahwa Media Wall Chart (bagan dinding) terhadap kemampuan menulis karangan argumentasi dapat meningkatkan keefektifan belajar.
\end{abstract}

Kata kunci: fuzzy servqual, Media Wall Chart, menulis, karangan, dan argumentasi

\section{Pendahuluan}

Berbahasa merupakan suatu perbuatan yang dilakukan oleh setiap manusia dalam kebersamaannya dengan manusia lain untuk berkomunikasi. Bahasa sebagai sarana komunikasi dapat berupa bahasa lisan, maupun bahasa tulis. Aktivitas menulis merupakan suatu bentuk manifestasi kemampuan (keterampilan) berbahasa yang paling akhir dikuasai pelajar bahasa setelah kemampuan mendengarkan, berbicara, dan membaca. Agar pembelajaran menulis itu mudah, diperlukan media pembelajaran yang tepat. Ada beberapa media pembelajaran yang dapat digunakan untuk pembelajaran menulis antara lain, media wall chart, media gambar seri, media poster, media iklan, media brosur dan masih banyak yang lainnya. Media wall chart akan diuji keefektifannya dalam pembelajaran menulis khususnya menulis karangan argumentasi.

Dengan dasar pemikiran di atas, permasalahan di dalam penelitian ini dirumuskan sebagai berikut: "Apakah pembelajaran kemampuan menulis karangan argumentasi dengan menggunakan media wall chart lebih efektif dibandingkan dengan kemampuan menulis karangan argumentasi tanpa menggunakan media wall chart pada siswa kelas X SMA Negeri?"

Dengan demikian, penelitian ini bertujuan untuk:

1. Mengetahui apakah ada perbedaan yang signifikan kemampuan menulis karangan argumentasi antara kelompok yang diberi pembelajaran dengan menggunakan media wall chart dengan 
kelompok yang diberi pembelajaran tanpa menggunakan media wall chart.

2. Membuktikan apakah penggunaan media wall chart lebih efektif digunakan dalam pembelajaran menulis karangan argumentasi siswa.

\section{Tinjauan Pustaka}

\section{Pengertian Menulis}

Menulis adalah aktivitas aktif produktif, aktivitas menghasilkan bahasa. Dilihat dari pengertian umum, menulis adalah aktivitas mengemukakan gagasan melalui media bahasa (Nurgiyantoro, 2009). Menulis adalah menurunkan atau melukiskan lambang-lambang grafik yang menggambarkan suatu bahasa yang dipahami seseorang sehingga orang lain dapat membaca lambang-lambang grafik tersebut, kalau mereka memakai bahasa dan lambang grafik tadi (Tarigan, 2008).

\section{Karangan Argumentasi}

Karangan argumentasi adalah ragam wacana yang dimaksudkan untuk menyakinkan pembaca mengenai kebenaran yang disampaikan oleh penulisnya. Oleh karena tujuannya untuk menyakinkan pendapat atau pemikiran pembaca, penulis akan menyajikan secara logis dan sistematis bukti-bukti yang dapat memperkuat keobjektifan dan kebenaran yang disampaikannya, sehingga menghapus konflik dan keraguan pembaca terhadap pendapat penulis. Corak karangan ini antara lain: hasil penilaian, pembelaaan, dan timbangan baku (Saadie, 2007).

\section{Pengertian tentang Media Wall Chart}

Wall chart merupakan suatu media pembelajaran yang dapat berupa gambar, denah, bagan, atau skema yang biasanya digantungkan pada dinding kelas. Kegunaan media ini adalah untuk melatih penguasaan kosakata dan penyusunan kalimat. Media wall chart sering disebut dengan bagan dinding karena media ini dapat digantungkan di papan tulis atau di dinding kelas. Salah satu bentuk dari media wall chart yang berupa gambar yaitu carta gambar. Carta gambar merupakan gambar semantis yang hampir mirip dengan gambar seri (Soeparno, 1988). Bedanya gambar seri merupakan gambar yang merupakan rangkaian cerita, sedangkan carta gambar merupakan gambar-gambar yang tidak menggambarkan suatu rangkaian cerita. Misalnya gambar yang dikelompokkan menurut jenisnya, seperti kelompok gambar benda bernyawa, kelompok benda tak bernyawa, kelompok gambar perbuatan, dan sebagainya (Soeparno, 1988).

\section{Teori Fuzzy}

Beberapa aspek di dunia nyata selalu atau biasanya berada di luar model matematis dan bersifat inexact. Ketidakpastian inilah yang menjadi konsep dasar munculnya logika fuzzy. Pada prinsipnya himpunan fuzzy adalah perluasan dari himpunan crisp, yaitu himpunan yang membagi sekelompok individu ke dalam dua kategori, anggota dan bukan anggota (Ross, 1995). Di dalam hampir setiap sistem rekayasa, dikenal dua sumber informasi penting:

1. Sensor yang memberikan pengukuran numerik dari suatu variabel.

2. Pakar (manusia) yang memberikan instruksi dan deskripsi tentang linguistik

Informasi yang didapatkan dari sensor adalah informasi numerik dan informasi yang berasal dari pakar manusia adalah informasi linguistik. Informasi numerik dinyatakan dalam bilangan, sedangkan informasi linguistik dinyatakan dalam kata- kata seperti kecil, besar, sangat besar, dan sebagainya. Pendekatan dalam rekayasa yang konvensional hanya dapat memanfaatkan informasi numerik dan mengalami kesulitan dalam memanfaatkan informasi linguistik.

Alasan informasi linguistik sering digambarkan dalam istilah fuzzy adalah:

1. Komunikasi yang dilakukan lebih cocok dan efisien jika dilakukan dalam istilah fuzzy. 
Jika pertukaran informasi dilakukan dalam angka-angka akan terasa sangat janggal, meskipun angka-angka memiliki tingkat presisi yang tinggi.

2. Pengetahuan kita tentang sesuatu hal pada dasarnya adalah bersifat fuzzy. Seringkali kita mengerti akan suatu teori, tetapi kita tidak yakin secara mendetail.

3. Banyak sistem nyata yang terlalu kompleks jika digambarkan dalam istilah crisp. Seringkali informasi penting mengenai suatu sistem tidak presisi. Dan kadangkala hanya informasi tersebut yang kita peroleh.

\section{Triangular Fuzzy Number}

Fuzzy number adalah special fuzzy set $F=\left\{\left(x_{,} \mu_{F}(x)\right), x \subset R\right\}$, di mana $x$ adalah nilainilai yang terletak pada garis bilangan riil $R^{1}:-\infty<x<+\infty$ dan $\mu_{F}(x)$ merupakan suatu pemetaan kontinu dari $\mathrm{R}^{1}$ ke dalam interval tertutup [0, 1] (Duboisdan Prade, 1980, dalam Chan dkk, 1999). Fuzzy number digunakan untuk menggambarkan konsep numerik yang tidak presisi, seperti "mendekati 7", "sekitar 8 atau 9", "kurang lebih 5", dan sebagainya.

Sebuah triangular fuzzy number (TFN), dinyatakan dengan $\mathrm{M}=(\mathrm{a}, \mathrm{b}, \mathrm{c})$, di mana $\mathrm{a}<\mathrm{b}<\mathrm{c}$, merupakan fuzzy number khusus dan memiliki membership function berjenis triangular

$$
\mu_{M}(x)=\left\{\begin{array}{l}
0, \quad x \leq a \text { atau } x \geq c \\
(x-a) /(b-a), a \leq x \leq b \\
(c-x) /(c-b), b \leq x \leq c
\end{array}\right.
$$

sebagai berikut:

\section{Pengukuran Service Quality}

Karena sektor jasa yang menghasilkan produk berupa pelayanan memiliki sifat yang khas (Arasli, dkk, 2005), maka penggunaan teknik manajemen kualitas standar tidaklah sesuai (Rahman, 2004). Karena sifatnya yang khas tersebut, beberapa peneliti dan akademisi mengembangkan beberapa metode untuk menemukan, mengukur, dan menganalisa determinan dari kualitas pelayanan (Arasli dkk., 2005). Dr. Noriaki Kano mengembangkan model Kano untuk mendapatkan preferensi pelanggan (Rahman, 2004). Cronin dan Taylor (1992, dalam Kim dkk., 2004) mengembangkan SERVPERF. Sedangkan metode SERVPEX dikembangkan oleh Robledo (2001, dalam Kim dkk, 2004).

Beberapa peneliti yang mengembangkan metode pengukuran kualitas pelayanan rumah sakit disebutkan di dalam (Rose, dkk, 2004). Kualitas pelayanan perlu diukur setidaknya karena tiga alasan (Brysland dan Curry, 2001):

1. Hasil pengukuran dapat digunakan untuk melakukan perbandingan antara sebelum dan sesudah terjadinya perubahan pada suatu organisasi.

2. Pengukuran diperlukan untuk menemukan letak permasalahan yang terkait dengan kualitas.

3. Hasil pengukuran diperlukan untuk menetapkan standar pelayanan kualitas.

\section{Metode Servqual}

Di antara berbagai model pengukuran kualitas pelayanan, servqual merupakan metode yang paling banyak digunakan (Wisniewski, 2001; Arasli dkk., 2005). Karena frekuensi penggunaannya yang tinggi, servqual dipandang memenuhi syarat validitas secara statistik (Brysland dan Curry, 2001).

\section{Metode Penelitian}




\section{Desain Penelitian}

Pada penelitian ini desain penelitian yang digunakan adalah pretes postes dengan kelompok kontrol (Control Group Pretest Postest Design). Pretes digunakan untuk mengukur kemampuan awal siswa dalam menulis karangan argumentasi, sedangkan postes digunakan untuk mengukur kemampuan akhir siswa dalam menulis karangan argumentasi setelah diberikan perlakuan yang berupa penggunaan media wall chart.

\section{Paradigma Penelitian}

Paradigma penelitian merupakan model realisasi antara variabel-variabel dalam suatu kegiatan penelitian. Paradigma penelitian ini dapat digambarkan sebagai berikut.

1. Paradigma Kelompok Eksperimen

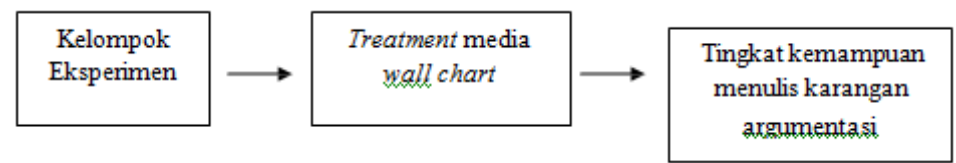

Gambar 1. Paradigma Kelompok Eksperimen

2. Paradigma Kelompok Kontrol

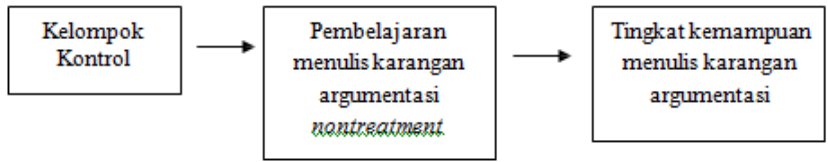

Gambar 2. Paradigma Kelompok Kontrol

Berdasarkan bagan paradigma penelitian di atas, variabel penelitian yang telah ditetapkan dikenai pengukuran dengan pretes. Manipulasi eksperimen menggunakan media wall chart untuk kelompok eksperimen dan perlakuan tanpa menggunakan media wall chart untuk kelompok kontrol. Selain itu, kedua kelompok dikenai pengukuran dengan menggunakan postes.

Tabel 1. Aspek Penilaian

\begin{tabular}{|c|c|c|}
\hline No & $\begin{array}{c}\text { Aspek } \\
\text { Penilaian }\end{array}$ & Kriteria Penilaian \\
\hline \multirow[t]{2}{*}{1} & Isi & $\begin{array}{l}\text { Tema dikembangkan dengan kreatif dan isi tidak keluar dari tema. } \\
\text { Kreativitas ada, tetapi pengembangan tema kurang. }\end{array}$ \\
\hline & & Pengembangan tema tidak ada dan kreativitas sangat kurang. \\
\hline \multirow[t]{2}{*}{2 . } & $\begin{array}{l}\text { Struktur } \\
\text { kalimat }\end{array}$ & $\begin{array}{l}\text { Struktur kalimat jelas, penggunaan kalimat tepat dan sangat efektif, peristiwa jelas dan } \\
\text { disertai contoh, bukti untuk memperkuat penjelasan. } \\
\text { Struktur kalimat kurang jelas, penggunaan kurang tepat dan kurang efektif, peristiwa } \\
\text { jelas namun tidak disertai contoh dan bukti untuk meperkuat cerita. }\end{array}$ \\
\hline & & $\begin{array}{l}\text { Struktur kalimat tidak jelas, penggunaan kalimat tidak tepat dan tidak efektif, peristiwa } \\
\text { tidak jelas serta tidak disertai contoh dan bukti. }\end{array}$ \\
\hline \multirow[t]{2}{*}{3.} & Bahasa & $\begin{array}{l}\text { Tidak terjadi kesalahan penggunaan bentuk kebahasaan dan menggunakan bahasa } \\
\text { denotative. }\end{array}$ \\
\hline & & $\begin{array}{l}\text { Terjadi sedikit kesalahan penggunaan bentuk kebahasaan serta masih terdapat sedikit } \\
\text { kata kiasan. } \\
\text { Terjadi banyak kesalahan penggunaan bentuk kebahasaan sehingga merusak makna } \\
\text { serta penggunaan kata konotatif lebih dominan daripada penggunaan kata denotatif. }\end{array}$ \\
\hline \multirow[t]{3}{*}{4.} & Ejaan dan tanda & Siswa memahami aturan penulisan kata dan tanda baca sesuai dengan EYD. \\
\hline & baca & Siswa kurang memahami aturan penulisan kata dan tanda baca sesuai dengan EYD. \\
\hline & & Siswa tidak memahami aturan penulisan kata dan tanda baca sesuai dengan EYD. \\
\hline
\end{tabular}


Kelima aspek/ dimensi di atas dinilai dengan menggunakan lima kategori pengukuran:

1. Kategori 1: sangat tidak baik/ sangat tidak memuaskan

2. Kategori 2: tidak baik/ tidak memuaskan

3. Kategori 3: cukup baik/ cukup memuaskan

4. Kategori 4: baik/ memuaskan

5. Kategori 5: sangat baik/ sangat memuaskan

Hasil dan Pembahasan

Uji Kecukupan Data

Uji kecukupan data dilakukan untuk menguji apakah data kuesioner yang diberikan telah cukup menggambarkan populasi pelanggan keseluruhan. Besarnya sampel penelitian ditentukan dengan mendasarkan pada jumlah populasi, di mana bila subjeknya lebih dari 100, maka digunakan ukuran sampel sebesar 10\%-15\% (Arikunto, 1998).

\section{Uji Validitas Data}

Tujuan dari pengujian ini adalah untuk mengetahui akurasi kuesioner yang disebarkan. Untuk mengetahui validitas instrumen, penelitian ini menggunakan korelasi product moment dengan angka kasar yang dikemukakan oleh Pearson sebagai berikut (Singarimbun dan Effendi (eds), 1989):

$$
r=\frac{N\left(\sum_{i=1}^{N} X_{i} Y_{i}\right)-\left(\sum_{i=1}^{N} X_{i} \sum_{i=1}^{N} Y_{i}\right)}{\sqrt{\left[N \sum_{i=1}^{N} X_{i}^{2}-\left(\sum_{i=1}^{N} X_{i}\right)^{2}\right]\left[N \sum_{i=1}^{N} Y_{i}^{2}-\left(\sum_{i=1}^{N} Y_{i}\right)^{2}\right]}}
$$

dimana:

$\mathrm{r} \quad$ : koefisien korelasi product momen

$\mathrm{X}$ : skor tiap pertanyaan/ item

Y : skor total

$\mathrm{N}$ : jumlah responden

\section{Hasil Penelitian}

Setelah pengujian dan pengolahan data, bahasan berikutnya di dalam makalah ini adalah hasil penelitian.

\section{Uji Kecukupan Data}

Dalam penelitian ini populasi adalah kelas XA, XB, XC, XD, XE, dan XF dengan jumlah 216 siswa. Dengan menetapkan besarnya jumlah data adalah sebesar $20 \%$ dari populasi, diperoleh besarnya sampel yaitu 36 siswa. Berdasarkan pendapat Arikunto (1998), data tersebut telah mencukupi.

\section{Analisis Uji Validitas Data}

Dari uji validitas data baik kuesioner awal maupun kuesioner akhir untuk setiap butir pertanyaan, diperoleh $r_{\text {hitung }}>r_{\text {tabel }}$, di mana pada tingkat keyakinan $0,95, r_{\text {tabel }}$ kuesioner awal $=0,514$ dan $r_{\text {tabel }}$ kuesioner akhir $=0,312$. Dengan demikian dapat disimpulkan bahwa semua butir pertanyaan tersebut adalah valid.

\section{Analisis Uji Reliabilitas Data}

Uji reliabilitas dilakukan dengan menggunakan reliability analysis yang terdapat pada SPSS for Windows versi 11.5. Koefisien korelasi yang digunakan sebagai penilaian terhadap reliabilitas instrumen adalah sebagai berikut:

1. $0,800-1,000=$ baik 
2. $0,600-0,799=$ dapat diterima

3. $<0,600=$ kurang baik

Dari hasil pengujian terhadap data kuesioner awal maupun kuesioner akhir menggunakan media wall chart dan tanpa menggunakan media wall chart, didapatkan nilai alpha pada rentang 0,600 - 0,799, sehingga kuesioner dinyatakan reliabel. Analisis Perhitungan Ratarata Crisp Penilaian dan Rata-rata TFN menggunakan media wall chart dan tan pa menggunakan media wall chart. Dengan melakukan perhitungan rata-rata crisp penilaian, dapat diketahui berapa nilai gap antara menggunakan media wall chart dan tanpa menggunakan media wall chart untuk tiap-tiap kriteria pelayanan. Sedangkan dengan melakukan perhitungan rata-rata TFN, dapat diketahui terdapat pada fungsi TFN berapakah nilai crisp rata-rata penilaian yang telah didapatkan.

Analisis Perhitungan Nilai Gap Kriteria menulis karangan argumentasi antara antara menggunakan media wall chart dan tanpa menggunakan media wall chart Kualitas menulis setiap kriteria menulis karangan argumentasi digambarkan oleh nilai gap antara penilaian menggunakan media wall chart kriteria karangan argumentasi dan penilaian tanpa menggunakan media wall chart terhadap kriteria yang sama. Nilai gap negatif menunjukkan kualitas karangan argumentasi suatu criteria kurang baik sehingga perlu ditingkatkan. Idealnya, nilai gap antara menggunakan media wall dan tanpa menggunakan media wall chart adalah nol. Dalam kondisi demikian, tanpa menggunakan media wall chart terhadap suatu kriteria karangan argumentasi adalah sama dengan menggunakan media wall chart terhadap kriteria yang sama. Bila nilai gap positif, maka hal itu menunjukkan bahwa menggunakan media wall chart terhadap kinerja suatu kriteria menulis karangan argumentasi melebihi tanpa menggunakan media wall chart terhadap kriteria yang sama. Semakin besar nilai negatif suatu gap pada suatu kriteria menulis karangan argumentasi, semakin besar pula prioritas peningkatan kualitas Keefektifan Penggunaan Media Wall Chart (bagan dinding) dari kriteria menulis karangan argumentasi tersebut. Berdasarkan perhitungan, nilai gap negatif tertinggi adalah pada kriteria menulis karangan argumentasi(Isi, Struktur Kalimat, Bahasa dan Ejaan dan tanda) yaitu -3,2. Sedangkan nilai gap negatif terendah adalah kriteria ejaan dan tanda. Berikut ini disajikan lima kriteria pelayanan yang memiliki nilai gap negatif tertinggi, seperti terlihat pada tabel 2 .

Analisis Gap Tiap Dimensi

Dengan melakukan perhitungan nilai gap tiap dimensi kualitas Keefektifan Penggunaan Media Wall Chart (bagan dinding), dapat diketahui sampai sejauh mana tingkat kesesuaian antara menggunakan media wall chart dan menggunakan media wall chart pada tiap-tiap dimensi tersebut. Dari hasil perhitungan, nilai gap negatif tertinggi adalah pada dimensi reliability dengan nilai gap sebesar $-3,100$. Sedangkan nilai gap negatif terendah terdapat pada dimensi assurance.

Tabel 2. Kriteria menulis karangan argumentasi dengan nilai gap negatif tertinggi

\begin{tabular}{ccccc}
\hline No. $\begin{array}{c}\text { Aspek } \\
\text { Penilaian }\end{array}$ & & \multicolumn{1}{c}{ Kriteria Penilaian } & $\begin{array}{c}\text { Nilai } \\
\text { Servqual }\end{array}$ & Peringkat \\
\hline $1 . \quad$ Isi & a. & $\begin{array}{l}\text { Tema dikembangkan dengan kreatif dan isi tidak keluar } \\
\text { dari tema. }\end{array}$ & & \\
& b. $\begin{array}{l}\text { Kreativitas ada, tetapi pengembangan tema kurang. } \\
\text { c. } \begin{array}{l}\text { Pengembangan tema tidak ada dan kreativitas sangat } \\
\text { kurang. }\end{array}\end{array}$ & $-3,200$ & 1 \\
\hline
\end{tabular}




\begin{tabular}{|c|c|c|c|c|c|}
\hline & $\begin{array}{l}\text { Struktur } \\
\text { kalimat }\end{array}$ & b. & $\begin{array}{l}\text { Struktur kalimat jelas, penggunaan kalimat tepat dan } \\
\text { sangat efektif, peristiwa jelas dan disertai contoh, bukti } \\
\text { untuk memperkuat penjelasan. } \\
\text { Struktur kalimat kurang jelas, penggunaan kurang tepat } \\
\text { dan kurang efektif, peristiwa jelas namun tidak disertai } \\
\text { contoh dan bukti untuk meperkuat cerita. } \\
\text { Struktur kalimat tidak jelas, penggunaan kalimat tidak } \\
\text { tepat dan tidak efektif, peristiwa tidak jelas serta tidak } \\
\text { disertai contoh dan bukti }\end{array}$ & $-3,150$ & 2 \\
\hline 3. & Bahasa & a. & $\begin{array}{l}\text { Tidak terjadi kesalahan penggunaan bentuk kebahasaan } \\
\text { dan menggunakan bahasa denotative. } \\
\text { Terjadi sedikit kesalahan penggunaan bentuk kebahasaan } \\
\text { serta masih terdapat sedikit kata kiasan. } \\
\text { Terjadi banyak kesalahan penggunaan bentuk kebahasaan } \\
\text { sehingga merusak makna serta penggunaan kata konotatif } \\
\text { lebih dominan daripada penggunaan kata denotative. }\end{array}$ & $-3,100$ & 3 \\
\hline 4. & $\begin{array}{l}\text { Ejaan dan } \\
\text { tanda } \\
\text { baca }\end{array}$ & a. & $\begin{array}{l}\text { Siswa memahami aturan penulisan kata dan tanda baca } \\
\text { sesuai dengan EYD. } \\
\text { Siswa kurang memahami aturan penulisan kata dan tanda } \\
\text { baca sesuai dengan EYD. } \\
\text { Siswa tidak memahami aturan penulisan kata dan tanda } \\
\text { baca sesuai dengan EYD. }\end{array}$ & $-3,050$ & 4 \\
\hline
\end{tabular}

Analisis Gap antara menggunakan media wall chart dan tanpa menggunakan media wall chart Keseluruhan berdasarkan perhitungan gap antara defuzzifikasi nilai menggunakan media wall chart serta defuzzifikasi nilai harapan pelanggan secara keseluruhan, didapatkan angka -3,361. Hal ini menunjukkan Keefektifan Penggunaan Media Wall Chart (bagan dinding) terhadap terhadap kemampuan menulis karangan argumentasi sudah terpenuhi, sehingga meningkatakan kualitas keefektifan media pembelajaran.

\section{Simpulan dan Saran}

\section{Simpulan}

Beberapa kesimpulan yang dapat diambil dari penelitian ini adalah sebagai berikut:

1. Siswa yang diberi pembelajaran dengan menggunakan media wall chart dalam menulis karangan argumentasi lebih bagus dibandingkan siswa yang diberi pembelajaran tanpa menggunakan media wall chart.

2. Penggunaan media wall chart dalam pembelajaran menulis karangan argumentasi lebih efektif dibandingkan pembelajaran tanpa menggunakan media wall chart.

\section{Saran}

Saran dari hasil penelitian ini adalah sebagai berikut:

1. Perlu diadakan penelitian selanjutnya untuk mengetahui pemanfaatan media wall chart dalam pembelajaran menulis karangan argumentasi dengan populasi yang lebih luas.

2. Media wall chart dapat dijadikan salah satu alternatif untuk meningkatkan keterampilan menulis, khususnya menulis karangan argumentasi.

\section{Daftar Pustaka}

Arasli, H.; Mehtap-Smadi, S.; dan Katircioglu, S.T. (2005). Customer Service Quality in The Greek Cypriot Banking Industry. Managing Service Quality, Vol. 15, No. 1, 41-56.

Arikunto, S. (1998). Prosedur Penelitian: Suatu Pendekatan Praktik, edisi revisi. Jakarta: Rineka Cipta.

Brysland, A.; dan Curry, A. (2001). Service Improvements in Public Services Using SERVQUAL. Managing Service Quality, Vol. 11, No. 6, 389-401.

Chan, L.K.; Kao, H.P; Ng, A.; dan Wu, M.L. (1999). Rating the Importance of Customer 
Needs in Quality Function Deployment by Fuzzy Entropy Methods. International Journal of production Research, Vol. 37, No. 11, 2499-2518.

Kim, Y.P.; Lee, S.H.; dan Yun, D.G. (2004). Integrating Current and Competitive ServiceQuality Level Analyses for Service-Quality Improvement Programs. Managing Service Quality, Vol. 14, No. 4, 288-296.

Nurgiyantoro, Burhan. (2009). Statistik Terapan untuk Penelitian Ilmu-ilmu Sosial. Yogyakarta: BPFE.

Rahman, Z. 2004. Developing Customer Oriented Service: a Case Study. Managing Service Quality, Vol. 14, No. 5, 426-435.

Rose, R.C.; Uli, J.; And, M.A.; dan Ng, K.L. (2004). Hospital Service Quality: a Managerial Challenge. International Journal of Health Care Quality Management, Vol. 17, No. 3, 146-159.

Saadie, Ma'mur. (2007). Strategi Pambelajaran Bahasa Indonesia. Jakarta: Unversitas terbuka.

Singarimbun, M.; dan Effendi, S.(eds.). (1989). Metode Penelitian Survai. Jakarta: LP3ES.

Wisniewski, M. ( 2001). Using SERVQUAL to Assess Customer Satisfaction with Public Sector Ervices.

Soeparno. (1988). Media Pengajaran Bahasa. Yogyakarta: PT. Intan Pariwara.

Tarigan, Henry Guntur. (2008). Menulis sebagai Suatu Keterampilan Berbahasa. Bandung: Angkasa. 